\title{
HOMEOPATHIC PRODUCT IN DOG DIETS MODULATE BLOOD CELL RESPONSES
}

(Produto homeopático em dietas de cães modula as respostas das células sanguíneas)

Maiara Sulzbach Marchiori ${ }^{1}$, Aleksandro Schafer Da Silva ${ }^{1,2,3}$, Patricia Glombowsky², Gabriela Campigotto ${ }^{2}$, Jorge Augusto Rosina Favaretto ${ }^{1}$, Antonise Mariely Jaguezeski ${ }^{3}$

\author{
1Departamento de Zootecnia, Universidade do Estado de Santa Catarina; ${ }^{2}$ Programa de Pós- \\ graduação de Zootecnia, Universidade do Estado de Santa Catarina; ${ }^{3}$ Programa de Pós-graduação \\ em Bioquímica Toxicológica, Universidade Federal de Santa Maria
}

1'Corresponding author: aleksandro_ss@yahoo.com.br

ABSTRACT: Every year, numbers and life expectancies of pets increase, especially for dogs and cats. Pets are exposed to environmental factors such as pollutants, pathogens, and oxidants that hamper the animals' ability to respond to stressors. Nutrition and hygiene are increasingly important among animal professionals and pet owners. The objective of this study was to evaluate the efficacy of a commercially-available homeopathic herbal product formulated with plants, designed to stimulate canine immunity. We used 10 male dogs (beagles) weighing $5.5-6 \mathrm{~kg}$ and 5 months of age. Animals were randomly allocated to Control $(C, n=5)$ and Treated $(T, n=5)$ groups. The treated group received a basal diet with an additional dose of $0.5 \mathrm{~mL} /$ animal/day homeopathic solution and group $\mathrm{C}$ received only the basal diet (300 g/day). The product was supplied for 45 days. The animals were weighed and blood samples collected for complete blood counts and serum biochemistry on days $1,15,30$ and 45 of the experiment. Higher numbers of lymphocytes were observed in conjunction with lower numbers of neutrophils in the $\mathrm{T}$ group on days 30 and 45 . Total and neutrophil leukocytes decreased throughout the experiment in both groups, and lymphocytes increased with significant difference only in the T group. Erythrocytes and hematocrit increased in both groups over time, as did glucose, triglycerides, total protein, albumin and urea levels. ALT was higher in the control group on day 45 . We conclude that the use of a homeopathic agent stimulated lymphocyte production in healthy dogs; and this suggests that homeopathic use is beneficial, because lymphocytes are directly related to cellular and humoral immune responses. Studies in adult animals and those focusing on infectious challenges may reveal more information about the actions of this homeopathic agent.

Keywords: Immunity, canines, homeopathy.

RESUMO - Todos os anos, o número e a expectativa de vida dos animais de estimação aumenta, especialmente para cães e gatos. Os animais de estimação são expostos a fatores ambientais, como poluentes, patógenos e oxidantes que dificultam a capacidade dos animais de responder aos efeitos do estresse. Nutrição e higiene são considerados fatores cada vez mais importantes para profissionais e proprietários de animais. O objetivo deste estudo foi avaliar a eficácia de um produto homeopático à base de plantas projetado para estimular a imunidade canina. Foram utilizados 10 cães machos (beagles) com peso entre 5,5 e $6 \mathrm{~kg}$ e 5 meses de idade. Os animais foram alocados aleatoriamente nos grupos Controle 
$(C, n=5)$ e Tratado $(T, n=5)$. O grupo tratado recebeu uma dieta basal com uma dose adicional de $0,5 \mathrm{~mL} / \mathrm{animal} / \mathrm{dia}$ de solução homeopática e o grupo $\mathrm{C}$ recebeu apenas a dieta basal ( $300 \mathrm{~g} / \mathrm{dia})$. $\mathrm{O}$ produto foi fornecido por 45 dias. Os animais foram pesados e as amostras de sangue coletadas para hemograma completo e bioquímica sérica nos dias 1, 15, 30 e 45 do experimento. Um número maior de linfócitos foi observado em conjunto com um número menor de neutrófilos no grupo $\mathrm{T}$ nos dias 30 e 45 . Os leucócitos totais e neutrófilos diminuíram ao longo do experimento em ambos os grupos, e os linfócitos aumentaram com diferença significativa apenas no grupo T. Os eritrócitos e o hematócrito aumentaram nos dois grupos ao longo do tempo, assim como os níveis de glicose, triglicerídeos, proteína total, albumina e ureia. A ALT foi maior no grupo controle no dia 45. Concluímos que o uso de um agente homeopático estimulou a produção de linfócitos em cães saudáveis; e isso sugere que o uso do produto homeopático foi benéfico, porque os linfócitos estão diretamente relacionados às respostas imunes celulares e humoral. Estudos em animais adultos e focados em desafios infecciosos podem revelar mais informações sobre as ações desse agente homeopático.

Palavras-chave - Imunidade, caninos, homeopatia.. 


\section{INTRODUCTION}

Pet ownership increases every year; in parallel, there are increased concerns regarding hygiene and other challenges to which pets are susceptible (Haverbeke et al. 2008; Vitale and Foss 2018). Inflammatory, infectious and chronic diseases can often be avoided or minimized by boosting the pet's immune system (Haverbeke et al. 2008; Vitale and Foss 2018). Immunity may be defined as those mechanisms that create defenses, recognizing, neutralizing and labelling antigens such that they are eliminated from the animals, avoiding damage to tissues and subsequent development of diseases (Eissa et al. 2019). The canine immune system includes natural barriers (the respiratory tract, skin and digestive tract), cellular defenses to repel invasion of microorganisms, and the humoral immune system, principally involving antibodies; these systems interact in a complex manner to preserve animal health (Tizard and Jones 2018). Homeopathy is derived from

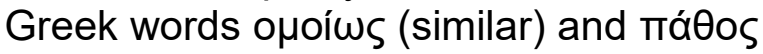
(suffering). In principle, homeopathy involves dilution of substances for preventive and curative for immune deficiencies; these agents are designed to develop immunity by simulating the disease it is meant to inhibit (Basu et al. 2017; Şenel 2019). Homeopathic products can be developed from highly diluted vegetable, mineral and animal ingredients; all of these have been used in both human and veterinary medicine (Unlu et al. 2017; Cermin et al. 2019). Because homeopathy is intended to improve immunity, these agents may decrease the use of conventional drugs that have been reported to cause environmental damage and public health (Fortuoso et al. 2019). Suástgui et al. (2019) reported increased bacterial resistance and pathogenicity on the part of bacteria caused by unnecessary and excessive use of antibiotics.
Homeopathic remedies have emerged as immune stimulating agents (Braghieri et al. 2007; Suástgui et al. 2009) improving animal health and making the environment safer. Therefore, the objective of this study was to evaluate the efficacy of a commercial homeopathic herbal product, designed to stimulate canine immunity.

\section{MATERIALS AND METHODS}

\subsection{Homeopathic product}

The homeopathic product ORGAIMUNI® (OrgaPet-Orgânica Homeopatia Veterinária, Chapecó, Santa Catarina, Brazil) was formulated based on Echinacea angustifolia $6 \mathrm{CH}$, Aconitum napellus $30 \mathrm{CH}$, Veratrum album $30 \mathrm{CH}$, Pyrogenium $200 \mathrm{CH}$, Calcarea carbonica $30 \mathrm{CH}$ and Ignatia amara $30 \mathrm{CH}$. The product was designed to improve canine immune responses, particularly aiding recovery in the convalescent state. The homeopathic mixture was administered by mixing with it with the dogs' feed that was offered twice a day to the treated group at a dose of $0.5 \mathrm{~mL} /$ animal/day.

\subsection{Animals and experimental design}

Dogs were maintained in an experimental kennel located in an experimental farm at the University of the State of Santa Catarina (UDESC Oeste). At the facility, the animals had access to the outdoor area with sunshine and interaction with other individuals, because they were kept in collective kennels. At night, they remained in the inner areas of two kennels, separated according to experimental groups. The room temperature was artificially adjusted to $25{ }^{\circ} \mathrm{C}$. Water was available ad libitum, while feed was composed of $300 \mathrm{~g}$ commercial canine ration divided into two daily portions, offered in individual kennels. This Project was approved by institutional Ethics Committee for Animal Experimentation. 
We used beagle dogs (Canis familiaris), aged 5 months and weighing between 5.5 and $6 \mathrm{~kg}$, previously treated with anthelmintics and a complete cycle of vaccines. The animals were randomly divided into groups, the control group ( $\mathrm{n}$ $=5)$ and the treated group $(n=5)$. Kennels were cleaned daily to minimize pathogen exposure.

The experiment lasted 45 days, during which time each animal was kept in an individual kennel while feeding, to ensure that the amount of food recommended per animal was ingested. The animals in the control group (C) received $300 \mathrm{~g}$ of feed with $0.5 \mathrm{~mL}$ of placebo solution (vehicle used to formulate the product) daily, and the treated group $(T)$ received the same amount of feed with the addition of 0.5 $\mathrm{mL}$ of compound ORGAIMUNI divided into two daily treatments, one at 8:00 $\mathrm{AM}$ and the other at 5:00 PM.

\subsection{Animal weights}

The animals were weighed using a digital scale on days $1,15,30$, and 45 of the experiment individually, before feeding.

\subsection{Sample collection}

Blood samples were taken on days $1,15,30$ and 45 . Samples were collected by jugular venipuncture using syringes, and blood was allocated in tubes with anticoagulant (EDTA) or without anticoagulant, kept refrigerated at $4{ }^{\circ} \mathrm{C}$ until processing (maximum time 2 hours). A $1 \mathrm{~mL}$ sample of EDTAcontaining blood was used to perform the complete blood counts. The sample without anticoagulant was centrifuged ( $800 \times \mathrm{g}$ for 10 minutes) to obtain serum for biochemical analyses, preserved at $10^{\circ} \mathrm{C}$ until use. All samples were taken from animals fasted for 10 to 12 hours, without restriction of water consumption.

\subsection{Hemogram}

Red cell count, total leukocytes and hemoglobin concentrations were measured using a CELM CC530 semiautomatic device. Hematocrit was measured using micro capillaries centrifuged at $1400 \times \mathrm{g}$ for 5 minutes. The leukocyte differential was done manually, using blood swabs stained using a Panótico Rápido kit.

\subsection{Serum biochemistries}

Serum levels of total protein (TP), albumin, urea, cholesterol, triglycerides, glucose and alanine aminotransferase (ALT) were measured using Analisa $\mathbb{R}$ kits and the semi-automatic BioPlus $2000 \AA$. Globulin levels were calculated by subtracting albumin from total protein levels.

\subsection{Statistical analysis}

The data were subjected to normality tests. Data not meeting normal distribution was transformed to logarithmic form. Comparisons were between groups made and over time using two-way ANOVA. Significance was considered when $\mathrm{P}<0.5$.

\section{RESULTS}

\subsection{Body weight}

Body weights did not differ between groups $(P>0.05$; Figure 1$)$. In both groups, growing animals (5 months old) increased weight over time.

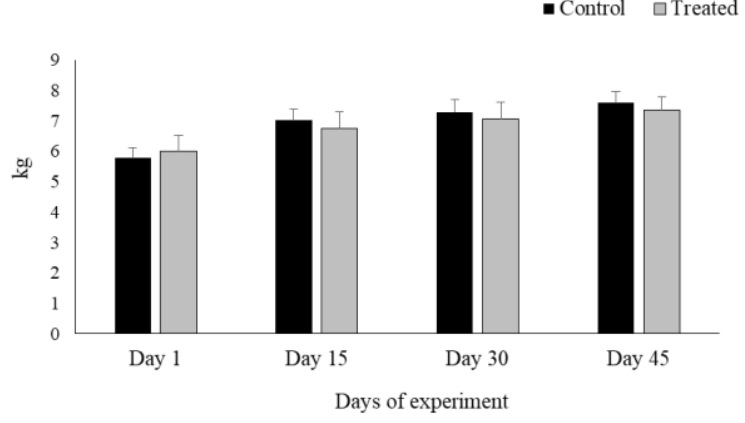

Figure 1: Body weight of dogs supplemented with ORGAIMUNI homeopathic product in a dose of $0.5 \mathrm{~mL} /$ animal/day administered during 45 days of experiment. Note: $P>0.05$, with no difference between groups. 


\subsection{Hemogram}

There were no significant differences between the groups in terms of eosinophil counts, monocytes, erythrocytes, hematocrit or hemoglobin $(P>0.05)$. However, lymphocyte counts were greater in the $\mathrm{T}$ group on days 30 and 45 of the experiment $(P<0.05)$. There were no differences in terms of time points, monocytes, eosinophils and hemoglobin levels between groups $(P>$ $0.05)$. However, erythrocyte counts were higher on days 15,30 and 45 in both groups compared to day $1(P<0.001)$. The decrease in the total number of leukocytes was observed concomitantly with the decrease of neutrophils on days 30 and 45 for the $T$ group and on day 45 in group $\mathrm{C}$, compared to day 1 ( $\mathrm{P}<$ 0.001 ), simultaneously with the increase in lymphocytes seen only in the group $T$ at days 30 and $45(P<0.05)$. Results of erythrocyte and leukocyte parameters are shown in Table 1.

\subsection{Serum biochemistries}

Between groups, the only parameter that showed a significant difference was total protein, which was lower on day 45 in the $T$ group $(P<$ 0.05). During the experimental period (between days), TP was higher in the T group on days 30 and 45 than on day 1 $(P<0.05)$ and on days 15,30 and 45 in group $C$ than on day $1(P<0.001)$. Albumin levels were higher in the $T$ group on days 15,30 and 45 and higher in group $C$ only on day 45 than on day 1 $(P<0.05)$. Globulin and cholesterol levels did not differ between days in the period evaluated for both groups $(P>$ $0.05)$. Glucose levels was higher on day 45 in the T group and on days 15 and 45 in group $C$ than on day $1(P<0.001)$. Triglyceride levels were higher on days 15 and 45 in group $T$ and 15,30 and 45 in group $\mathrm{C}$ compared to day 1 ( $\mathrm{P}<$ $0.001)$. Urea levels were higher on days 15,30 and 45 in the $T$ group and on days 30 and 45 in group $C$ than on day 1
$(P<0.001)$. ALT differed only in group $\mathrm{C}$; it was greater on days 15 and 30 than on days 1 and $45(P<0.01)$.

Table 1: Hematologic parameters of dogs supplemented with Orgaimuni homeopathic product in the dose at 0.5 $\mathrm{mL} / a n i m a l / d a y$ for 45 days of experiment.

\begin{tabular}{|c|c|c|c|c|}
\hline Variable & Collection day & Treated & Control & P-value* \\
\hline \multirow[t]{5}{*}{ Erythrocytes $\left(\times 10^{6} \mu \mathrm{L}\right)$} & 1 & $4.20(0.23)^{\mathrm{b}}$ & $4.27(0.30)^{\mathrm{b}}$ & 0.82 \\
\hline & 15 & $6.50(1.15)^{\mathrm{a}}$ & $7.18(1.33)^{\mathrm{a}}$ & 0.51 \\
\hline & 30 & $8.08(1.28)^{\mathrm{a}}$ & $6.68(1.06)^{\mathrm{a}}$ & 0.24 \\
\hline & 45 & $6.96(1.30)^{\mathrm{a}}$ & $5.72(0.40)^{\mathrm{a}}$ & 0.19 \\
\hline & P-value ${ }^{\#}$ & 0.001 & 0.001 & \\
\hline \multirow[t]{5}{*}{ Hematocrit (\%) } & 1 & $31.6(2.6)^{b}$ & $32.2(1.64)^{\mathrm{b}}$ & 0.80 \\
\hline & 15 & $36.2(2.5)^{\mathrm{a}}$ & $36.6(3.2)^{\mathrm{ab}}$ & 0.86 \\
\hline & 30 & $34.2(1.3)^{\mathrm{ab}}$ & $35.0(3.4)^{\mathrm{ab}}$ & 0.79 \\
\hline & 45 & $35.6(5.1)^{\mathrm{ab}}$ & $36.0(1.8)^{\mathrm{a}}$ & 0.62 \\
\hline & P-value & 0.001 & 0.001 & \\
\hline \multirow[t]{5}{*}{ Hemoglobin (g/dL) } & 1 & $10.1(0.86)$ & $10.08(0.60)$ & 0.92 \\
\hline & 15 & $11.06(0.70)$ & $11(0.79)$ & 0.93 \\
\hline & 30 & $10.22(0.43)$ & $10.68(0.32)$ & 0.90 \\
\hline & 45 & $11.5(1.29)$ & $11.26(0.69)$ & 0.81 \\
\hline & P-value & 0.32 & 0.10 & \\
\hline \multirow[t]{5}{*}{ Leukocytes $\left(\mathrm{x} 10^{3} \mu \mathrm{L}\right)$} & 1 & $8.22(0.92)^{a}$ & $9.88(1.75)^{\mathrm{a}}$ & 0.21 \\
\hline & 15 & $8.50(0.9)^{\mathrm{a}}$ & $8.92(2.0)^{\mathrm{ab}}$ & 0.62 \\
\hline & 30 & $6.52(1.3)^{b}$ & $7.24(1.14)^{a b}$ & 0.35 \\
\hline & 45 & $6.56(1.0)^{\mathrm{b}}$ & $7.08(0.38)^{\mathrm{b}}$ & 0.45 \\
\hline & P-value ${ }^{\#}$ & 0.001 & 0.01 & \\
\hline \multirow[t]{5}{*}{ Neutrophils $\left(\times 10^{3} \mu \mathrm{L}\right)$} & 1 & $4.86(0.71)^{\mathrm{a}}$ & $5.36(0.87)^{\mathrm{a}}$ & 0.56 \\
\hline & 15 & $4.99(0.77)^{\mathrm{a}}$ & $5.03(1.3)^{\mathrm{ab}}$ & 0.89 \\
\hline & 30 & $2.01(0.50)^{\mathrm{b}}$ & $4.14(1.06)^{a b}$ & 0.01 \\
\hline & 45 & $2.09(0.5)^{\mathrm{b}}$ & $3.64(0.16)^{b}$ & 0.001 \\
\hline & P-value & 0.001 & 0.001 & \\
\hline \multirow[t]{5}{*}{ Lymphocytes $\left(\mathrm{x} 10^{3} \mu \mathrm{L}\right)$} & 1 & $2.72(0.54)^{\mathrm{b}}$ & $3.48(1.3)$ & 0.26 \\
\hline & 15 & $2.69(0.37)^{b}$ & $3.33(1.16)$ & 0.23 \\
\hline & 30 & $3.98(1.0)^{\mathrm{a}}$ & $2.32(0.25)$ & 0.02 \\
\hline & 45 & $3.90(1.1)^{\mathrm{a}}$ & $2.54(0.33)$ & 0.04 \\
\hline & Valor $\mathrm{P}^{\#}$ & 0.05 & 0.09 & \\
\hline \multirow[t]{5}{*}{ Monocytes $\left(\times 10^{3} \mu \mathrm{L}\right)$} & 1 & $0.42(0.19)$ & $0.55(0.23)$ & 0.68 \\
\hline & 15 & $0.43(0.22)$ & $0.32(0.20)$ & 0.56 \\
\hline & 30 & $0.38(0.10)$ & $0.35(0.21)$ & 0.74 \\
\hline & 45 & $0.38(0.14)$ & $0.46(0.23)$ & 0.65 \\
\hline & P-value & 0.65 & 0.53 & \\
\hline \multirow[t]{5}{*}{ Eosinophils $\left(\times 10^{3} \mu \mathrm{L}\right)$} & 1 & $0.22(0.13)$ & $0.33(0.23)$ & 0.67 \\
\hline & 15 & $0.41(0.21)$ & $0.22(0.15)$ & 0.39 \\
\hline & 30 & $0.12(0.05)$ & $0.40(0.28)$ & 0.16 \\
\hline & 45 & $0.15(0.03)$ & $0.23(0.11)$ & 0.50 \\
\hline & P-value & 0.08 & 0.21 & \\
\hline
\end{tabular}

${ }^{*} P<0.05$ shows a difference between groups at each collection time. \# $P<0.05$ shows the difference over time, identified by different letters in the same column. 


\section{Biochemical parameters between groups and between time points are displayed in Table 2.}

Table 2: Serum biochemical parameters of dogs supplemented with Orgaimuni homeopathic product at a dose of 0.5 $\mathrm{mL} /$ animal/day for 45 days (Cont.).

\begin{tabular}{ccccc}
\hline Variable & $\begin{array}{c}\text { Collection } \\
\text { day }\end{array}$ & Treated & Control & P-value* \\
\hline Glucose & 1 & $104.8(7.3)$ & $94.2(10.8)$ & 0.29 \\
$(\mathrm{mg} / \mathrm{dL})$ & & $\mathrm{b}$ & $\mathrm{b}$ & \\
& 15 & 126.2 & 120.2 & 0.54 \\
& & $(19.3)^{\mathrm{ab}}$ & $(11.3)^{\mathrm{a}}$ & \\
& 30 & 108.8 & 109.6 & 0.65 \\
& & $(10.6)^{\mathrm{b}}$ & $(22.6)^{\mathrm{ab}}$ & \\
& 45 & 130.6 & 123.4 & 0.60 \\
& & $(12.1)^{\mathrm{a}}$ & $(10.1)^{\mathrm{a}}$ & \\
& P-value $^{\#}$ & 0.001 & 0.001 &
\end{tabular}

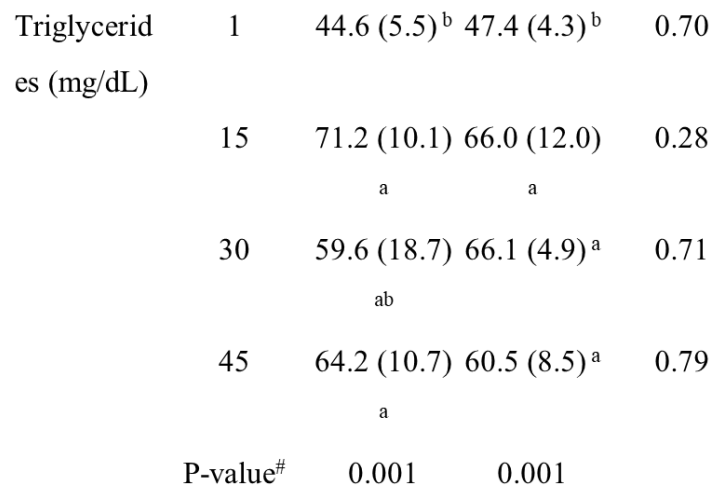

$\begin{array}{lcccc}\text { Cholestero } & 1 & 152.4 & 138.0 & 0.54 \\ 1(\mathrm{mg} / \mathrm{dL}) & & (27.3) & (31.1) & \\ & 15 & 161.0 & 157.2 & 0.69 \\ & & (42.9) & (21.8) & \\ & & 154.2 & 162.6 & 0.65 \\ & & (26.2) & (49.7) & \\ & & 160.6 & 183.0 & 0.38 \\ & & (26.4) & (43.8) & \\ & & & \\ & & & \\ & & & & \\ & & & & \end{array}$

Table 2. Cont.:

\begin{tabular}{|c|c|c|c|c|}
\hline Variable & $\begin{array}{c}\text { Collection } \\
\text { day }\end{array}$ & Treated & Control & P-value* \\
\hline \multirow[t]{5}{*}{$\begin{array}{l}\text { Total protein } \\
(\mathrm{g} / \mathrm{dL})\end{array}$} & 1 & $5.28(0.04)^{b}$ & $5.26(0.32)^{b}$ & 0.94 \\
\hline & 15 & $6.10(1.0)^{\mathrm{ab}}$ & $6.78(0.54)^{\mathrm{a}}$ & 0.74 \\
\hline & 30 & $6.68(0.9)^{\mathrm{a}}$ & $6.98(0.54)^{\mathrm{a}}$ & 0.81 \\
\hline & 45 & $6.44(0.31)^{\mathrm{a}}$ & $7.36(0.60)^{\mathrm{a}}$ & 0.05 \\
\hline & P-value ${ }^{\#}$ & 0.02 & 0.001 & \\
\hline \multirow{5}{*}{$\begin{array}{l}\text { Albumin } \\
(\mathrm{g} / \mathrm{dL})\end{array}$} & 1 & $2.44(0.11)^{b}$ & $2.42(0.22)^{b}$ & 0.95 \\
\hline & 15 & $3.56(0.59)^{\mathrm{a}}$ & $2.88(0.38)^{\mathrm{ab}}$ & 0.12 \\
\hline & 30 & $3.40(0.72)^{\mathrm{a}}$ & $3.08(0.37)^{\mathrm{ab}}$ & 0.31 \\
\hline & 45 & $3.42(0.31)^{\mathrm{a}}$ & $3.74(1.0)^{\mathrm{a}}$ & 0.46 \\
\hline & P-value ${ }^{\#}$ & 0.001 & 0.02 & \\
\hline \multirow{5}{*}{$\begin{array}{l}\text { Globulin } \\
(\mathrm{g} / \mathrm{dL})\end{array}$} & 1 & $2.84(0.13)$ & $2.84(0.28)$ & 0.91 \\
\hline & 15 & $2.54(1.1)$ & $3.90(0.82)$ & 0.08 \\
\hline & 30 & $3.66(0.6)$ & $3.90(0.56)$ & 0.86 \\
\hline & 45 & $3.02(0.28)$ & $3.84(0.77)$ & 0.21 \\
\hline & P-value ${ }^{\#}$ & 0.09 & 0.18 & \\
\hline
\end{tabular}

$\begin{array}{ccccc}\text { Urea (mg/dL) } & 1 & 30.4(2.6)^{\mathrm{c}} & 33.2(6.7)^{\mathrm{b}} & 0.80 \\ & 15 & 41.4(5.6)^{\mathrm{b}} & 45(9.1)^{\mathrm{ab}} & 0.64 \\ & 30 & 50.6(9.0)^{\mathrm{ab}} & 44.2(3.34)^{\mathrm{a}} & 0.49 \\ & 45 & 57.8(5.4)^{\mathrm{a}} & 56.6(11.5)^{\mathrm{a}} & 0.83 \\ & & & & \\ \text { ALT (U/L) } & 1 & 40.2(15.4) & 38.6(4.3)^{\mathrm{b}} & 0.68 \\ & 15 & 65.6(17.1) & 56(4.9)^{\mathrm{a}} & 0.57 \\ & 30 & 55.6(13) & 57.2(10.0)^{\mathrm{a}} & 0.68 \\ & 45 & 51.6(8.3) & 41.0(5.87)^{\mathrm{b}} & 0.24\end{array}$

$\begin{array}{lll}\text { Valor } \mathrm{P}^{\#} & 0.06 & 0.01\end{array}$

Note: ALT (alanine aminotransferase). $\mathrm{P}<0.05$ shows a difference between groups at each collection time. \#P<0.05 shows the difference over time, identified by different letters in the same colun. 


\section{DISCUSSION}

Homeopathic agents have been used to enhance immune function in animals with increasing intensity in recent years (Remya and Kuttan 2015; Mazón-Suástegui et al. 2017). The study present is the first report of the use of homeopathic compound Echinacea angustifolia, Aconitum napellus, Veratrum album, Pyrogenium, Calcarea carbonica and Ignatia amara to evaluate the general health of growing dogs. Phytotherapeutics and minerals are used to form mixtures of compounds with properties of interest for immunological improvement. With the growing interest in companion animals, studies are being conducted to evaluate the effects of these agents on health and quality of life. Homeopathy is considered an alternative for prevention and cure of various diseases, by boosting an individual patient's immune responses (Haverbeke et al. 2008; Vitale and Foss 2018). The plants used in this study are known for immunomodulatory properties; as for example researchers demonstrated that Echinacea is a widespectrum immunomodulator that modulates both innate and adaptive immune responses (Zhai et al. 2007); anti-inflammatory properties of jervine, a sterodial alkaloid from rhizomes of Veratrum album (Dumlu et al. 2019); Pyrogenium changes the leukocyte chemotaxis (Poitevin et al. 1983); immuno-modulatory effect during Calcarea carbonica-mediated tumor apoptosis (Saha et al. 2013); Ignatia amara is promising agents with anti inflammatory effect (Anser and Najam 2015); and researchers reported that Aconitum napellus is a homeopathic medicine for the sudden onset of acute inflammation (Guyon 2018).

During the experiment, weight gain increased in both groups, explained by the growth and hygienic stages in which they were tested. Increased hematocrit and erythrocyte counts in both groups are also explained by their age, because the reference values increased over time, stabilizing in adulthood; this occurs as a result of the transition of hematopoietic organs from embryonic phase to adult phase, when the process becomes more efficient in the marrow, in addition to the higher tissue requirements (Weiser and Alisson 2015).

Decreased leukocyte counts were accounted for by decreased neutrophil counts in both groups. The low white blood cell count in healthy animals is expected because there is no need for them to destroy pathogens (Salami 2018; Duan et al. 2019). The increase in lymphocytes in the $T$ group at the end of the experiment could be explained by an improvement in organism defenses against infectious agents that are activated by cellular and humoral mechanisms (Ramishetti and Peer 2018); however, only the globulin fraction could verify our hypothesis, because its increase over time was not significant in the treated group. In other studies, activation of lymphocytes was observed with the use of homeopathic (Leal et al. 2012; Abud et al. 2006; Burbano et al. 2009; Cesar et al. 2008). We believe that the increase in lymphocytes in the $\mathrm{T}$ group and the decrease in the $C$ group may be related to chronic stress experienced by the animals. The stressor agent causes stimulation of the hypothalamus, which in turn synthesizes corticotropinreleasing hormone (CRH). CRH acts on adenohypophysis, stimulating the secretion of adrenocorticotropic hormone $(\mathrm{ACTH})$, which stimulates the adrenal cortex to secrete glucocorticoids (Vale et al. 1981). In this way, chronic stress caused by confinement or loneliness would increase cortisol secretion (Gonzalez et al. 2003); according to Tventen and Raskin (2012), this would result in lymphopenia with or 
without neutrophilia, where lymphopenia is the most consistent finding. Decreased circulating lymphocyte counts are the result of sequestration by lymphoid tissues (Gonzalez et al. 2003). Thus, the return of lymphocytes to normal counts indicates good recovery from stress (Tventen and Raskin 2012), and it is possible to assume that the homeopathic agent reduced the stressful condition, resulting in increased lymphocyte counts. In challenging circumstances, we believe these animals are better able to respond adequately to pathogens.

Total protein levels increased in both groups because of increases in albumin levels, because growth requires more hepatic synthesis to meet tissue demands. Albumin carries several compounds in the circulation, including triglycerides (Nemashkalova et al. 2019), and its levels are modulated as needed. Albumin is also the main biomarker of increased dietary protein in animals (Wada et al. 2017), resulting in greater amounts of metabolic products and urea at the end of its cycle. This increased protein/albumin/urea ratio was observed in both groups, being therefore directly related to diet and better utilization of components. However, globulin, a parameter that contributes to the total protein value, did not differ among treatments, suggesting that the increase was due to $T$ lymphocytes. This is because $B$ lymphocytes, if increased in number, are expected to increase globulin levels, including the gamma fraction, whereas immunoglobulins are produced primarily by B lymphocytes. The lymphopenia presented in dogs in group $\mathrm{C}$ may be related to chronic stress (Tvedten and Raskin 2015) that was minimized by administering homeopathic product. Assuming that there has been an increase in the number of $T$ lymphocytes, there may have been an increase in pro-inflammatory molecules such as cytokines, which are very important in the immune response and in the fight against aggressive pathogens, as well as several other bodily functions. The biochemical parameters underwent random variations, possibly explained by varied fasting time on collection days, as well as the growth status of the animals, because their metabolism is much faster than that of adults (Alisson 2015). However, we should also consider the hypothesis that chronic stress and chronic activation as well as HPA axis dysregulation may lead to metabolic dysfunction, because glucocorticoids are important regulators of glucose metabolism and insulin sensitivity (Bose et al. 2009).

ALT values increased inexplicably on the last day of evaluation of the control animals. Because we studied young, healthy animals, it is unlikely that the increase in ALT was related to hepatic lesions (Karatzas et al. 2014); this assumption is reinforced the fact that the ALT increase was temporary during the experiment, decreasing by the last day.

\section{CONCLUSIONS}

The use of a homeopathic agent stimulated lymphocyte production in healthy dogs. This suggests that homeopathic use is beneficial, because lymphocytes are directly related to cellular immune responses in terms of memory and humoral defense, enabling faster responses to micro-organisms. Studies in adult animals and those focusing on infectious challenges may reveal more information about the actions of this homeopathic agent.

\section{REFERENCES}

ALEKSSEV AE, REYES S, SELIVANOV VA, DZEJA PP, TERZIC A (2012) Compartmentation of membrane processes and nucleotide dynamics in diffusion-restricted cardiac cell 
microenvironment. Journal Molecular Cellular Cardiology 52:401-409.

ABUD APR, CESAR B, CAVAZZANI LFM, DE OLIVEIRA CC, GABARDO J, BUCHI DF (2006) Activationof bone marrow cells treated with Canova in vitro. Cell Biology Internaational. 30:808-816.

ALISSON RW (2015) Avaliação Laboratorial do Pâncreas e Metabolismo da Glicose. In: Thrall MA. et al., Hematologia e Bioquímica Clínica Veterinária. Roca, 2a edição, p.367.

BASU A, SURESH AK, KANE SG, BELLARE JR (2017) A review of machines and devices to potentize homeopathic medicines. Homeopathy 106:240-249.

BOSE M, OLIVAN B, LAFERRERE B (2009) Stress and obesity: the role of the hypothalamic-pituitary-adrenal axis in metabolic disease. Current Opinion Endocrinology Diabetes Obesity 16:340-346.

BRAGHIERI A, PACELLI C, VERDONE $M$, NAPOLITANO $F$ (2007) Effect of grazing end homeopathy on milk production and immunity of Merino derived ewes. Small Ruminant Research 69:95-102.

BURBANO RR, LEAL MF, DA COSTA JB, BAHIA MO, DE LIMA PDL, KHAYAT AS, SELIGMAN IC, DE ASSUNÇÃO PP, BUCHI DF, SMITH MAC (2009) Lymphocyte proliferation stimulated by activated human macrophages treated with Canova. Homeopathy 98:45-48.

Cermin A, Berry C, Burton S, Howlett E (2019) The effects of the FTC-mandated disclosure on homeopathic product purchase intentons and efficacy perceptions. Journal of Business Research 101:47-58.

CESAR B, ABUD APR, DE OLIVEIRA CC, CARDOSO F, GREMKI W, GABARDO J, BUCHI DF (2008) Activation of mononuclear bone marrow cells treated in vitro with a complex homeopathic medication. Micron 39:461-470.
DUAN Y, WANG J, HU M, ZHOU M, LI Q, SUN L, QIU S, WANG Y (2019) Leukocyte classification based on spatial and spectral features of microscopic hyperspectral images. Optics \& Laser Technology 112:530-538.

EISSA N, KITTANA H, NETO JCG, HUSSEIN H (2019) Mucosal immunity and gut microbiota in dogs with chronic enteropathy. Research in Veterinary Science 122:156-164.

FEITOSA KCO, POVH JA, DE ABREU JS (2013) Physiological responses of pacu (Piaractus mesopotamicus) treated with homeopathic product and submitted to transport stress. Homeopathy 102:268-273.

FORTUOSO BF, GEBERT RR, GRISS LG, GLOMBOVISKY P, CAZAROTTO CJ, RAMPAZZO L, STEFANI LM, FERREIRA EB, DA SILVA AS (2019) Reduction of stool bacterial counts and prevention of diarrhea using an oral homeopathic product in newborn lambs. Microbial Pathogenesis 127:347-351. FORTUOSO BF, VOLPATO A, RAMPAZZO L, GLOMBOWSKY P, GRISS LG, GALLI GM, STEFANI LM, BALDISSERA MD, FERREIRA EB, MACHADO G, DA SILVA AS (2018) Homeopathic treatment as an alternative prophylactic to minimize bacterial infection and prevent neonatal diarrhea in calves. Microbial Pathogenesis 114:95-98.

GONZÁLEZ FHD, SILVA SC (2003) Introdução a Bioquímica Clínica Veterinária. Porto Alegre: UFRGS

HAVERBEKE A, DIEDERICH C, DEPIEREUX E, GIFFROY JM (2008) Cortisol and behavioral responses of working dogs to environmental challenges. Physiology \& Behavior 93:59-67.

KARATZAS T, NERI AA, BAIBAKI ME et al (2014) Rodent models of hepatic ischemia-reperfusion injury: time and percentage-related pathophysiological mechanisms. Journal Surgy Research 191:399-412. 
LEAL MF, ANTUNES LMG, LAMARÃO MFV, DA SILVA CEA, DA SILVA IDCG, ASSUMPÇÃO PP, ANDRADE EF, REZENDE AP, IMBELONI AA, MUNIZ JAPC, PINTO GR, SMITH MAC, BURBANO RR (2012) The protective effect of Canova Homeopathic medicine in cyclophosphamide-treated nonhuman primates. Food and Chemical Toxicology 50:4412-4420.

MAZÓN-SUÁSTEGUI JM, GARCÍABERNAL M, SAUCEDO PE, CAMPACÓRDOVA Á, ABASOLO-PACHECO F (2017) Homeopathy outperforms antibiotics treatment in juvenile scallop Argopecten ventricosus: effects on growth, survival, and immune response. Homeopathy 106:18-26.

NEMASHKALOVA EL, PERMYAKOV EA, UVERSKY VN, PERMYAKOV SE, LITUS EA (2019) Effect of Cu2+ and $\mathrm{Zn} 2+$ ions on human serum albumin interaction with plasma unsaturated fatty acids. International Journal of Biological Macromolecules. Doi: 10.1016/j.ijbiomac.2019.03.085

RAMISHETTI S, PEER D (2018) Engineering linphocytes with RNAi. Advanced Drug Delivey Reviews. 2018: S0169-409X(18)30304-1.

SALAMI F, TAVASSOLI A, MEHRZAD J, PARHAM A (2018) Immunomodulatory effects of mesenchymal stem cells on leukocytes with emphasis on neutrophils. Immunobiology 223:786-791.

ȘENEL E (2019) Evolution of homeopathy: A scientometric analysis of global homeopathy literature between 1975 and 2017. Complementary Therapies in Clinical Practice 34:165173.

SUÁSTEGUI JMM, BERNAL MG, SUACEDO PE, CÓRDOVA ÁC, PACHECO FA (2017) Homeopathy outperforms antibiotics treatment in juvenile scallop Argopecten ventricosus: effects on growth, survival, and imune response. Homeopathy 106:18-26.
TIZARD IR, JONES SW (2018) The Microbiota Regulates Immunity and Immunologic Diseases in Dogs and Cats. Veterinary Clinics of North America: Small Animal Practice 48:307-322.

TUNGNUNGA IB, SARMA K, ROYCHOUDHURY $P$, BORTHAKUR SK, DAS G, PRASAD H, BEHERA SK (2016) Therapeutic evaluation of homeopathic drug Crotalus horridus 200 C against Ehrlichiosis-infected dogs in mizoram. Indian Journal of Research in Homoeopathy 10:42-51.

TUPE RS, KULKARNI A, ADESHARA $\mathrm{K}$, SHAIKH S, SHAH N, JADHAV A (2015)

jambolanum and Cephalandra

indica homeopathic preparations inhibit albumin glycation and protect erythrocytes: an in vitro study.

Homeopathy 104:197-204.

TVEDTEN H, RASKIN RE (2012) Leukocyte Disorders. In: Willard, M.D. and Tvedten, H. Small Animal: Clinical Diagnosis by Laboratory Methods. Elsevier. 5:63.

UNLU A, KRIRK O, OZDOGAN M (2017) Homeopathy and cancer. Journal of Oncological Sciences 3:7780.

VALEN W, SPIESS J, RIVIER C, RIVIER J (1981) Characterization of a 41-residue ovine hypothalamic peptide that stimulates secretion of corticotropin and beta-endorphin. Science 213:13941397.

VALSALAKUMARI R, GIRIJA K (2015) Homeopathic remedies with antineoplastic properties have immunomodulatory effects in experimental animals. Homeopathy 104:211-219.

VITALE S, FOSS K (2019) ImmuneMediated Central Nervous System Disease-Current Knowledge and Recommendations. Topics in Companion Animal Medicine 34:2229. 
WADA Y, SATO Y, MIYAZAKI K, TAKEDAY, KUWAHATA M (2017) The reduced/oxidized state of plasma albumin is modulated by dietary protein intake partly via albumin synthesis rate in rats. Nutrition Research 37:46-57.

WEISER G, ALISSON RW (2015) Considerações sobre interpretação de dados laboratoriais e diagnóstico de doenças. Thrall MA et al. Hematologia e Bioquímica Clínica Veterinária. Roca, 2a ed., p.34. 2015.

WILLS BW, PEARSON J, HSU A, LI P, SHAH A, NARANJE S (2019) Preoperative hematocrit on early prosthetic joint infection and deep venous thrombosis rates in primary total hip arthroplasty: A database study. Journal of Clinical Orthopaedics and Trauma 10:124-127. 